\title{
The Effect Of Information Search Toward Students' Reading Comprehention
}

\author{
Edi Firman', M. Asrul Hasby ${ }^{2}$ \\ Faculty of Culture, Management and Business. \\ University of Mandalika \\ edifirman@ikipmataram.ac.id, muhammadasrulhasby@gmail.com
}

\begin{abstract}
This study was intended to analyze whether Information has significant effect toward students' reading comprehension. The method of this research was quantitative approach and applied pre-experimental design by using pre-test and post-test. The population of this research was whole of the first-grade students of SMKS DARUL QUR'AN BENGKEL which was consisted of one class with the total number of populations was 29 students in X TKJ Group Class as population sample. The class was treated by using Students Information Search. The instrument used in this research was reading test, in form of multiple choices test which was consisted of 25 items. The data was analyzed using t-test. The result of the data analysis indicated that Information Search has significant effect towards students' reading comprehension. The result of statistical computation confirmed that the result of sig. two-tailed is differ from the value significant level $(0.000 \neq 0.05)$. the researcher also found the result of t-table was 2.061 lower then t-test 12.679. This result indicated that Alternative Hypothesis was accepted and Null Hypothesis was rejected, therefore it can be concluded that there is significant effect of Information Search towards students' reading comprehension.
\end{abstract}

Key Words: Information Search, Reading Comprehension.

Abstrak. Penelitian ini bertujuan untuk mencari tahu apakan information search memberikan dampak signifikan terhadap kemapuan membaca. Metode penelitian yang digunakan dalam penelitian ini adalah pendekatan kuantitatif dengan menggunakan desain pre-experimental pre-test post-tes. Populasi dalam penelitian ini adalah seluruh siswa kelas sepuluh SMKS DARUL QUR'AN BENGKEL yang terdiri dari satu kelas dengan total populasi berjumlah 29 siswa pada kelas X TKJ dan juga sebagai sample. Treatmen yang digunakan adalah Information Search. Instrument yang digunakan dalam penelitian ini adalah test membaca yang terdiri dari 25 soal pilihan ganda. Data analisis menunjukkan bahwa nilai significantnya adalah berbeda dengan nilai alfa $\alpha=0.05(0.000 \neq 0,05)$. Atau hasil t-test menunjukkan bahwa t-table 2.061 lebih rendah daripada nilai t-test 12.679. hasil ini membuktikan bahwa alternative hypothesis diterima dan null hyphotesis ditolak. Kesimpulanya adalah Information Search berdapak signifikan terdapat kemampuan membaca siswa.

Key Words: Information Search, Reading Comprehension.

\section{INTRODUCTION}

Reading is one of skills in English that should be mastered by students; Instead of listening, writing, and speaking. Reading is the process of making meaning from the text $(\mathrm{G}$. Wooley: 15:2011). It means that, reading is a process to gain an overall understanding of what is described in the text to obtain the meaning of the word or sentences. By using this skill, the readers try to understand what the idea or the information of a text wanted to deliver by the writer. Mastering reading skill also becomes a goal for all of the students who learn English as a foreign language.

The difficulties that students face arise due to the position of English as foreign language which is significantly influences by the use of English in daily life. It is used in classrooms but not in everyday communication (Harmer, Jeremy. 2003). States that Reading is influenced the by ability of mastering vocabulary comprehension, main idea, pacific fact or detail and lack of background knowledge of the topic can be the 
problem why the text is difficult to be comprehended.

The observation at SMKS Darul Qur'an Bengkel indicated that there are some students' difficulties comprehending reading text; some of the students could not find the main idea of the text. This difficulty could be seen from the students' difficulty in finding general statement of the text that they have read before. They could not identify detail information from the passage, such as dates, the name of place, and the name of people, and they could not make inference from the text. It could be seen on how students are difficult to make their own perception with their own words regarding to the text. The students confuse to draw a conclusion after reading the text. Those problems above exist because of the students less in reading comprehension.

In order to solve all of the problems, the researcher will applied information search strategy in teaching reading, hopefully those strategy able upgrade the students' skill. Information Search is a strategy that affords students an opportunity to study outside of the classroom, which sometimes feels bored and full of rules inside of the classroom, they can go to libraries, internet, cafe, while they are under control of the teacher.

\section{RESEARCH METHOD}

In this research, the researcher applied quantitative approach. Quantitative approach is the presentation of data in form of numeric and to analysis the data is using statistical. Miller (2005: 4) says that informal terms an experimental is a means of collecting evidence to show the effect of on variable upon another. Where, in this design consisted one experimental group without control group. For that reason, the research design that was used in this study is experimental design in the form of pre-experimental design.

\section{Population and Sample of the study}

According to Sugiyono (2017: 61) "population is generalization region that contain: object or subject which has certain quality and characteristic that is decided by the researcher for study and then to take the conclusion." It means that the population contains all of subject to be researched by researcher. The population in this research was theentire first grade of SMKS Darul Qur'an Bengkel consisting of one class with total number 29 students.

Sample is part of population's characteristics, if the populations is too many, and impossible for researcher to learn every part of it because of limited fund, personnel and time, then the researcher took some parts of the population (Sugiyono:2017:62)

Furthermore, sugiyono (2017:67) state that total sampling is the technique of determining sample if all of members of populations were taken as sample this technique is often used because the total of population small, less than 30, the researcher took all of the students at the first grade of SMKS Darul Qur'an Bengkel in academic year 2019/2020.

\section{Research Instrument}

\section{Reading test}

The test was consisted of 25 items multiple choice. each test consisted of 4 options (a, b, c, or d). Every correct answer gets 1 score and wrong answer gets 0 score; therefore, the maximum score is 25

\section{Technique of Collecting Data}

1. Pre-test

Pre-test was a test to evaluate the preparedness of students for further studies. Pre-test was the test given to students before they received treatment.

2. Post-test

Post-test was the test that used to acquire value after receives the treatment. In this research, Post-test is the test that used to know the effect information search towards students' reading comprehension. The post-test was given after receiving treatment.

\section{Technique of Data Analysis}

The researcher used descriptive statistic and inferential statistic to calculate all of data.

1. Descriptive Statistics

According to Kothari (2004: 131), descriptive statistics concern the development of certain indices from the raw data. The first step to analyze all of the data, the researcher used descriptive statistics to process the raw data becomes mean, median, mode and standard 
deviation to be processed to inferential statistics. The researcher used SPSS 19.0 for Windows by using method The Frequency Command to get the value of mean, median, mode and standard deviation.

2. Inferential Statistics

Inferential statistics is analysis derived from sample data that are used to make inferences about the population from which the sample is taken. In this research, the researcher used t-test to compute the data which is the interval and derived from pre-test and post-test to find out the significant difference between pretest and posttest. To get the value of t-test, the researcher used SPSS 19.0 for Windows by using the method Independent Samples t-test criteria:

a. If the value of sig-( 2 tailed $) \neq 0.05$, the alternative hypothesis is accepted.

b. If the value of sig-( 2 tailed $)=0.05$, the null hypothesis is accepted.

\section{Research Finding and Discussion}

In this chapter, the researcher presented the result of the research. The design was selected for one experimental group without control group. The total population is Theen tire first grade of SMKS Darul Qur'an Bengkel consisting of one class with total number 29 students. .

Data of the study were obtained from two steps: pre-test and post-test. Pre-test was conducted to measure students' reading comprehension before having treatment, then the second steps were post-test and the result of post-test showed us the students' capability after the treatment given of the samples. Experimental group treated by information search as the strategy.

1. Descriptive Statistics

The mean score of posttests is higher than pretest in experimental group $(76.38>50.17)$ and the median score of posttest is higher than pretest $(80.00>50.00)$ and the mode score of posttest is higher than pre-test $(80>45)$

2. Data Analysis

a. Normality Test
Normality test is used to find out whether the spreading data is distributed normally or not. In this study, the normality test used Kolmogorov-Smirnov strategy in which the significance level $\alpha=0,05$ as the rule to accept or reject the normal test.

b. Homogeneity Test

Beside normality test, one pre-requisite which is needed the most to analyze the data is homogeneity test. The purpose of this test is to find out whether the designed groups are homogenous the groups we designed. The homogeneity test for the data of Reading Comprehension is performed using Levene's test in the significant level of $5 \%$.

c. Inferential Analysis

The results of sig.(2-tailed) is 0.000 which is not similar to the value of significant level $0.05,(0.000 \neq 0.05)$. It means the alternative hypothesis is accepted.

And the result of t-test proved that t-test score is 12.679 higher that $\mathrm{t}$-table was 2.061 .

\section{DISCUSSION}

Based on statement of the problem that already formulated by researcher, the researcher tried to solve students' reading problems by implementing Information Search strategy. Researcher began the research by giving pre-test to experimental group to measure students' reading comprehension. After that, the researcher gave treatment to the sample, in the last meeting researcher gave the post-test to know the result of treatment.

After computing the result of the data analysis, it was found that information search has significant effect towards students' reading comprehension. It showed that the mean score of posttests is higher than pretest. The mean score of posttests was 76.38 and the mean score of pre-test was 50.17 (76.38 > 50.17). Furthermore, based on inferential statistical computation, the result of sig.-(2.tailed) 0.000 is lower than significant level $0.05,(0.000 \neq$ 0.05). At the end, from the result of testing hypothesis in t-test formula showed that, t-test value was 12.679 and t-table was 2.061. Therefore, the score of t-test is higher than ttable $(12.679>2.061)$, it can be concluded that 
the Alternative Hypothesis (Ha), which stated: "there is significance effect of information search towards students' reading comprehension was accepted and Null Hypothesis (Ho), which stated; "There is no significance effect of information search towards students' reading comprehension was rejected

\section{CONCLUSION AND AND SUGGESSION}

\section{Conclusion}

Based on the results of statistical computation, showed that the sig. two-tailed was not similar to the value significant level $(0.000 \neq 0.05)$. Those, the alternative hypothesis is accepted. It is indicating that the used of information search positively can increase the students' reading comprehension.

The researcher also found the results of $t$ table was 2.061 and t-test was12. 679, t-test was higher than t-table and Alternative Hypothesis was accepted, and the Null Hypothesis was rejected.

Furthermore, the result of descriptive statistic of computation showed the mean score of posttests was 76.38 and the mean score of pretests was $50.17(76.38>50.17)$. This indicates that hypothesis is accepted, which mean that the used of information search is positively effective toward students' reading comprehension.

\section{Suggestion}

Derived from data analysis and the result of research, the researcher would like to offer some suggestions to be considered next searcher and some people who interested teaching English;

This research might be not a perfect research, but the strategy on this research may be able to enrich the teaching strategies, technique and mode, because the varieties strategies of teaching might lead the students into deep comprehension. This teaching strategy also proved effective to be applied in teaching English, specially teaching reading comprehension.

The researcher hope that the result of this study also can be useful for the next researcher as the reference that would like to conduct research on similar theme.

\section{REFERENCES}

Brown, H.Douglas.(2004). Language Assessment-Principles and Classroom Practices. California: Pearson Longman.

Catherine, (2002). Reading for Understanding Toward an R\&D Program in Reading Comprehension: Rand

Chesla. 2002. Toefl Exam success from learning express in only 6 steps. United stated by learning express, LLC, New York.

Cohen, (2007). Research Methods in Education: the USA and Canada by Routledge

Gerry Wolly. 2011. Reading Comprehension: assisting children in lesrning difficulties. Griffith university

Grellet, (1981). Developing Reading Skills: the Press Syndicate of the University of Cambridge

Hamruni,2012:279.: "The effect of Information Search toward students' understanding concept in IPS at Madrasah Ibtidaiyah Negri 1 MuaraEnim.

Harmer, Jeremy. 2003. The Practice of English Language Teaching. Cambridge, UK:Longman Press.

HisyamZaini,2007: 55. "The effect of Information Search toward students' understanding concept in IPS at Madrasah Ibtidaiyah Negri 1 MuaraEnim.

Interventions, and Technologies. New Jersey: Lawrence Erlbaum Associates,Inc., Publishers

Johnson, Andrew P. (2008). Teaching Reading and Writing. A Guidebook for Tutoring and Remediating Students UK: Rowman \& Littlefield, Inc.

Kothari,C. R. 2004. Research Methodology. Methods and Techniques.New Age International (P) Limited, Publishers.

Marsha L. Roit EdD, (1998). Effective Teaching Srategies for Improving Reading Comprehension in $K-3$ Students: Canada by Routledge

McNamara, Danielle S. 2007. Reading Comprehension Strategies: Theories, 
Patel, M. E., \& Jain, P. M. (2008). English language teaching (Method, tools, Technique). Jaipur: Sunrise Publishers \& Distributors.

Steve Miller, (2005). Experimental Design and Statistics: the Taylor \& Francis eLibrary

Sugiyono. 2017. StatistikaUntukPenelitian. Bandung: PenerbitAlfabeta Bandung 